\title{
The in Vitro Anti-Diabetic Activity of Lime Peels (Citrus Amblycarpa (HASSK.) OCHSE)
}

\section{Gempita Cahaya Aulia Tambunan}

Prima University of Indonesia

\author{
Aparna Dutt \\ Prima University of Indonesia \\ Sayra Nadhifa \\ Prima University of Indonesia \\ Firdha Amelia \\ Prima University of Indonesia \\ Ermi Girsang \\ Prima University of Indonesia, ermigirsang@unprimdn.ac.id
}

\begin{abstract}
There are various potential natural anti-diabetic drugs; one of them is lime peel or Citrus amblycarpa. This study was aimed to explore the anti-diabetic activity and phytochemical content of lime peels. This study was an quasy experimental study that used the post-test only control group design. The lime peels that were collected from the Berastagi fruit market in Medan, North Sumatera were extracted using $70 \%$ ethanol by maceration methods. The phytochemical screening identified the presence of phenolic, steroid/triterpenoid, terpenoid, saponin, flavonoid, tannin, and alkaloid. Meanwhile, the anti-diabetic activity of lime peels was evaluate using the $\alpha$-glucosidase enzyme that was gotten from Saccharomyces cerevisiae by $\alpha$-glucosidase enzyme inhibition methods. Percent of inhibition was express as Mean \pm SD and analyzed by One Way ANOVA, Tukey HSD Post Hoc Test, and followed by linear regression. The result of this study showed that there is a significant difference in percentage inhibition $\alpha$-glucosidase enzyme in each concentration, and it had an IC50 Value amount of $125.93 \pm 9.14 \mu \mathrm{g} / \mathrm{mL}$. The phytochemical content of the lime peels was flavonoid, phenol, steroid/triterpenoid, and alkaloid. Hence, the lime peel has anti-diabetic activity by inhibition of the $\alpha$-glucosidase enzyme.
\end{abstract}

Keywords: Lime peel, $\alpha$-glucosidase enzyme, anti-diabetic, Citrus amblycarpa

\section{INTRODUCTION}

Diabetes Mellitus Type 2 or Insulin Independent Diabetes Mellitus is a chronic disease that requires intense treatment and strategies to reduce risk factors and control blood glucose. Based on the estimation of WHO (World Health Organization), around 171 million people over the world in 2000 suffered from diabetes and will increase and reach 366 million people in
2030. Meanwhile, based on the estimation of ADA (American Diabetic Association), the cost of diabetic care in the United States spends a national funds amount of \$US 132 billion in 2002 and will increase to \$US 192 billion in 2020 (American Diabetes Association, 2015; World Health Organization, 2016).

The prevalence of diabetes in Indonesia was reported by an annual report 
named Riskesdas in 2013 showed that the prevalence of diabetes was 1.5 percent in Indonesia that was diagnosed by the doctor, and the prevalence varied in several provinces in Indonesia. The top three provinces that had diabetes mellitus people that were diagnosis by the doctor were Yogyakarta (2.6\%), Jakarta (2.5\%), North Sulawesi (2.4\%), and East Kalimantan (2.3\%) (Badan Penelitian Dan Pengembangan Kesehatan Kementerian Kesehatan RI, 2013).

There are four types of oral antihyperglycemic drugs. These were insulin sensitive sensitizing, insulin secretagogues, glucosidase inhibitors, and incretins. Acarbose is one of the oral antihyperglycemic drugs that inhibit the $\alpha$ glucosidase enzyme in the human body. This drug acts as a competitive inhibitor for $\alpha$-glucosidase enzyme (Soegondo, 2017).

Glucosidase enzyme is an enzyme that catalyzes the hydrolysis of glycoside bonds in oligosaccharides or glycoconjugates. This enzyme specifically hydrolyzes the glycoside bond in the sugar molecule. There are two types of this enzyme, these were alpha and betaglucosidase that hydrolyze the glycoside bonds in both alpha and beta form. The alpha glucoside bond is a glucose bond with the hydroxyl group under the plane of the ring, while the beta bond is above the ring plane (Borges de Melo, da Silveira Gomes and Carvalho, 2006; Gordon, 2010).

As one of the oral antiHyperglycemic drugs, glucosidase enzyme inhibitor is a competitive inhibitor against the alpha-glucosidase enzyme. This enzyme is found in the brush border of the intestine to hydrolyze oligosaccharide, trisaccharide, and disaccharide. On the other hand, this enzyme is also found in the liver that prevents glycogenolysis for control the blood glucose level in the normal range (Borges de Melo, da Silveira Gomes and Carvalho, 2006; Naquvi et al., 2011).

There are various natural sources that had anti-diabetic activity by inhibition of alpha-glucosidase enzyme with various degrees of inhibition. These are Gymnrma sylvestre, Momordica charantia, Trigonella foenum graecum, Pterocarpus marsupium, Murraya koenigii, and other natural sources that have the inhibition activity. One of these natural sources that have not been explored in the anti-diabetic activity is lime (Citrus amblycarpa). Another type of Citrus' has anti-diabetic activity through the alpha-glucosidase inhibition or amylase enzyme inhibition. Citrus amblycarpa, as part of Citrus, may have the same anti-diabetic activity. The preceding study that was reported by Putra et al. (2018) showed that the ethanol 
extract of Citrus amblycarpa leaf has several phytochemicals like flavonoid, polyphenol, tannin, and glycoside that was also found in the other type of Citrus that showed the anti-diabetic activity (Putra, Satriawati and Astuti, 2018). Based on the information above, this study was aimed to explore the anti-diabetic activity of the lime (Citrus amblycarpa) peel and its phytochemical content.

\section{METHODS}

This was an experimental study that used the post-test only control group design. The lime that was used in this study was gotten from the Berastagi fruit market in Medan, North Sumatera. The lime was identified in the Herbarium Laboratory of School of Life Sciences and Technology - Science Program in Bandung Institute of Technology. While overall of this research was conducted in the Aretha Medika Utama Biomolecular and Biomedical Research Center in Bandung.

The lime was washed, and the fruit peel was separated from the fruit pulp. This was dried by a food dehydrator and meshed into Simplicia powder. The simplicia powder was extracted using $70 \%$ ethanol for 24 hours by maceration methods. After that, these were filtered, and the residue was re-macerated for two days. Meanwhile, the filtrate of maceration and re-maceration process was collected to be evaporated by a rotary vacuum evaporator at $50^{\circ} \mathrm{C}$ to form a concentrated form of extracts that were known as ethanol extract of lime peel and seed (Widowati et al., 2014, 2016, 2017; Widowati, Widya Janeva, et al., 2018).

Before the $\alpha$-glucosidase enzyme inhibition assay was performed, the ethanol extract was performed the phytochemical screening process based on the procedure that was described by Widowati et al. (Widowati et al., 2016, 2017; Widowati, Widya Janeva, et al., 2018). The phytochemical screening identified the presence of phenolic, steroid/triterpenoid, terpenoid, saponin, flavonoid, tannin, and alkaloid.

The $\alpha$-glucosidase enzyme inhibition assay should be begun by preparing the enzyme solution. The enzyme solution was made by mixing $1 \mathrm{mg}$ of the $\alpha$-glucosidase enzyme into $100 \mathrm{ml}$ buffer phosphate $(\mathrm{pH}$ 7.0) that contain $200 \mathrm{mg}$ of bovine serum albumin prior to being used the solution had to dissolve by $1 / 50$ of buffer phosphate. Furthermore, the amount of 25 $\mu \mathrm{L}$ of enzyme solution was mixed into substrate solution that contains $25 \mu \mathrm{L}$ pnitrophenyl $\alpha$-D-glucopyranoside $20 \mathrm{mM}$ as the substrate, $45 \mu \mathrm{L}$ buffer phosphate, and $5 \mu \mathrm{L}$ sample solution (DMSO solution as the control). This mixture was incubated 
in the $37^{\circ} \mathrm{C}$ for 30 minutes. After that, the reaction was terminated by adding $100 \mu \mathrm{L}$ $0,2 \mathrm{M} \mathrm{Na}_{2} \mathrm{CO}_{3}$ solution. The absorbance was measured at $400 \mathrm{~nm}$ wavelength by spectrophotometry, and the percent of enzym inhibition was determined by the following formulation (Widowati et al., 2011; Gondokesumo, Kusuma and Widowati, 2017; Pujimulyani et al., 2018; Widowati, Wargasetia, et al., 2018):

$$
\frac{(C-S)}{C} \times 100 \%
$$

$\mathrm{C}$ : Absorbance of the control

S: Absorbance of the sample

The percentage of enzyme inhibition was express as Mean $\pm \mathrm{SD}$. The percent of enzyme inhibition was analyzed by One Way ANOVA and followed by Tukey HSD Post Hoc Test. Furthermore, the analysis was continued by linear regression to determine the Inhibition Concentration $50\left(\mathrm{IC}_{50}\right)$ of each extract.

\section{RESULT}

\section{Identification of Sample}

The result of the identification of the sample that was used in this study was showed that it was lime or Jeruk Sambal in Indonesia that had scientific name Citrus amblycarpa (Hassk.) Ochse.

Kingdom : Plantae

Division : Magnoliophyta

Class : Magnoliopsida

Subclass : Rosidae

Ordo : Sapindales
Family : Rutaceae

Genus : Citrus

Species : Citrus amblycarpa (Hassk.)

Ochse

Synonym : Citrus limonellus var.

amblycarpa Hassk.

\section{Yield of Extract}

This study was used lime peels as the sample. The sample was extracted using $70 \%$ ethanol by maceration methods. The yield of extraction is shown by the following table.

Table 1 The yield of Ethanol Extract from Lime Peel

\begin{tabular}{|c|c|c|c|c|c|}
\hline $\begin{array}{l}\text { Weigh } \\
\text { t of } \\
\text { Simpli } \\
\text { cia } \\
\text { Powde } \\
\text { r } \\
(\mathrm{g}) \\
\end{array}$ & $\begin{array}{l}\text { The } \\
\text { volu } \\
\text { me of } \\
70 \% \\
\text { Ethan } \\
\text { ol }\end{array}$ & $\begin{array}{l}\text { Duratio } \\
\mathrm{n} \text { of } \\
\text { Macerat } \\
\text { ion }\end{array}$ & $\begin{array}{c}\text { Volu } \\
\text { me of } \\
\text { Filtrat } \\
\text { e }\end{array}$ & $\begin{array}{l}\text { Weig } \\
\text { ht of } \\
\text { Extra } \\
\text { ct }(g)\end{array}$ & $\begin{array}{l}\text { Yiel } \\
\mathrm{d} \text { of } \\
\text { Extra } \\
\text { ct }\end{array}$ \\
\hline 150 & $\begin{array}{l}500 \\
\mathrm{~mL}\end{array}$ & $\begin{array}{l}\text { Three } \\
\text { days }\end{array}$ & $\begin{array}{l}350 \\
\mathrm{~mL}\end{array}$ & 59.6 & 39.7 \\
\hline
\end{tabular}

\section{Phytochemical Screening}

The result of the phytochemical screening of Ethanol extract from Lime Peels is shown by the following table.

Table 2 The Screening Phytochemical of Lime Peels Extract

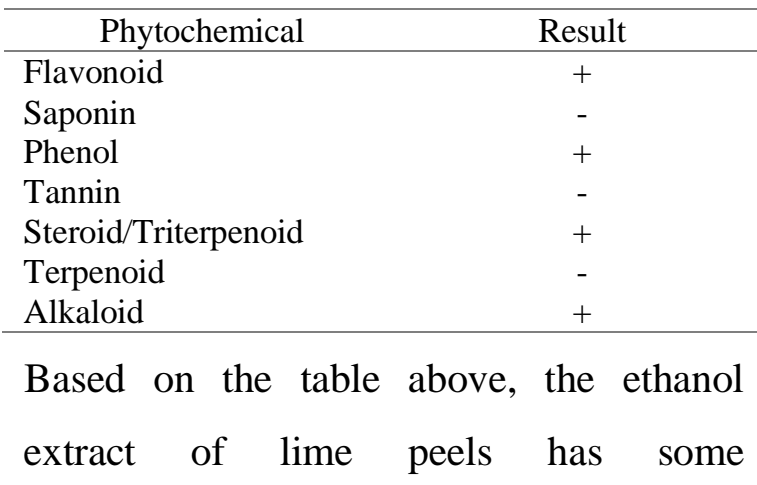


phytochemicals includes flavonoid, phenol, steroid/triterpenoid, and alkaloid.

\section{a-Glucosidase Enzyme Inhibition Assay}

The result of the $\alpha$-Glucosidase enzyme inhibition assay was shown as a percent of inhibition. Furthermore, the percent of $\alpha$ Glucosidase enzyme inhibition was compared among each group of concentration, and the result of the comparison was shown by the following table.

Table 3 Comparison of $\alpha$-Glucosidase enzyme inhibition Activity in each concentration of Ethanol Extract from Lime Peel

\begin{tabular}{lc}
\hline Concentration $(\mu \mathrm{g} / \mathrm{mL})$ & $\begin{array}{c}\text { Percent of Inhibition } \\
(\%)\end{array}$ \\
\hline 3.13 & $6.60 \pm 0.83^{\mathrm{a}}$ \\
6.25 & $12.79 \pm 1.16^{\mathrm{ab}}$ \\
12.50 & $12.30 \pm 1.36^{\mathrm{ab}}$ \\
25.00 & $16.33 \pm 1.61^{\mathrm{b}}$ \\
50.00 & $24.73 \pm 0.95^{\mathrm{c}}$ \\
100.00 & $45.20 \pm 0.55^{\mathrm{d}}$ \\
200.00 & $73.05 \pm 6.21^{\mathrm{e}}$ \\
\hline
\end{tabular}

Data were expressed as Mean \pm SD.

The difference superscript showed significance at $\mathrm{P}$-Value $<0.05$ based on the Tukey HSD Post Hoc Test.

Based on the table above, the lower concentration showed a significant difference in percentage inhibition at $\mathrm{P}$ Value $<0.05$. However, at the higher concentration, the difference in percentage inhibition was not significant. It means that in higher concentration, the reaction was begun to be saturated. Furthermore, the analysis was continued by linear regression to determine the $\mathrm{IC}_{50}$ value, and the result of the analysis was showed by the following table.

Table 4. Analysis of Linear Regression against Percentage Inhibition

\begin{tabular}{|c|c|c|c|c|}
\hline Repetition & Equation & $\mathrm{R}^{2}$ & $\begin{array}{l}\mathrm{IC}_{50} \\
(\mu \mathrm{g} / \mathrm{mL})\end{array}$ & $\begin{array}{l}\mathrm{IC}_{50} \\
(\mu \mathrm{g} / \mathrm{mL})\end{array}$ \\
\hline $\begin{array}{l}\text { First } \\
\text { repetition }\end{array}$ & $\begin{array}{c}Y= \\
0.3614 x \\
+7.4823\end{array}$ & 0.99 & 117.65 & \\
\hline $\begin{array}{l}\text { Second } \\
\text { repetition }\end{array}$ & $\begin{array}{c}Y= \\
0.2982 x \\
+9.5231\end{array}$ & 0.98 & 135.74 & 125.93 \\
\hline $\begin{array}{l}\text { Third } \\
\text { repetition }\end{array}$ & $\begin{array}{c}Y= \\
0.333 x+ \\
8.5752\end{array}$ & 0.99 & 124.40 & \pm 9.14 \\
\hline Average & $\begin{array}{c}Y= \\
0.3309 x \\
+8.5269\end{array}$ & 0.99 & 125.33 & \\
\hline
\end{tabular}

Based on the table above, the IC50 of ethanol extract from lime peels was 125.95 $125.93 \pm 9.14 \mu \mathrm{g} / \mathrm{mL}$. It means that it required $135.07-116.79 \mu \mathrm{g} / \mathrm{mL}$ ethanol extract of lime peels to inhibition $50 \%$ of $\alpha$-Glucosidase.

\section{DISCUSSION}

The result of this study showed that the increasing concentration of ethanol extract leads to an increase in the inhibition activity against the $\alpha$-Glucosidase enzyme. That was shown by the following figure.

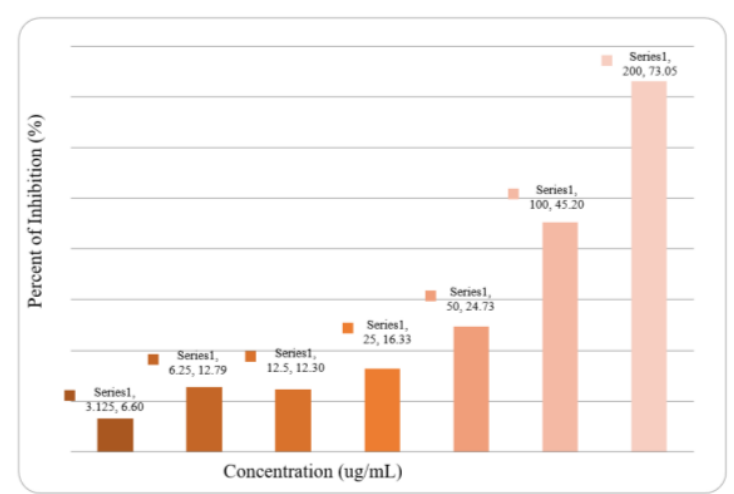


Figure 1. Effect of Various Concentration of Ethanol Extract from Citrus amblycarpa against Inhibition of $\alpha$-Glucosidase Enzyme

The $\alpha$-Glucosidase enzyme is usually found in the human intestine to degrade carbohydrates. This enzyme hydrolyzed the $\alpha$-glycoside bone on the oligosaccharide and produced $\alpha$-D-glycoside or glucose. The method that used to evaluation of the inhibition activity was based on the ability of sample for inhibiting the reaction of the enzyme against p-nitrophenyl- $\alpha$-Dglucopyranoside ( $\mathrm{p}-\mathrm{NPG}$ ), and this reaction would produce $\alpha$-D-glucose and $p$ nitrophenyl that had a yellow color. The reaction was shown by the following figure (Widowati et al., 2011; Gondokesumo, Kusuma and Widowati, 2017; Pujimulyani et al., 2018; Widowati, Wargasetia, et al., 2018).

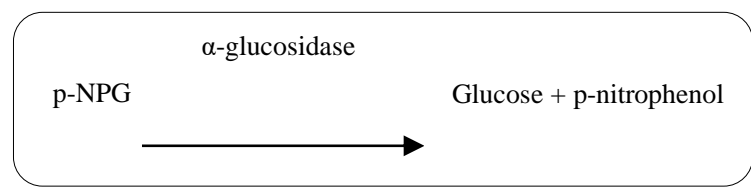

Figure 2 The Hydrolysis Reaction of pNPG

The anti-diabetic activity of ethanol extracts from lime peels due to the presence of phenolic compounds like flavonoids and tannins that can inhibit the carbohydrate-hydrolyzing enzymes. This statement was supported by the result of Bouabid et al. (2018). They reported that aqueous and methanol extract of Atractylisgummifera $\mathrm{L}$. that was rich in the phenolic compound had anti-diabetic activity through inhibition of $\alpha$-amylase, $\alpha$-glucosidase, and $\beta$-galactosidase (Bouabid et al., 2018).

The preceding study about the antidiabetic activity of lime peel still not available yet. However, there are several studies that explore other pharmacologic activity of lime, and these were an antioxidant activity, repellant, and antimicrobial activity from the peel, seed, and fruit pulp of lime (Kusumaningrum, 2015; Apriliani, Ramadhan and Rijai, 2017; Stevenie et al., 2019).

As a comparison, the following table would show the anti-diabetic activity of some types of orange peel, which was reported by Lim and Loh (2016) (Lim and Loh, 2016).

Table 5 The Anti-Diabetic Activity of Some types of orange

\begin{tabular}{|c|c|c|c|}
\hline \multirow[b]{2}{*}{ Sample } & \multirow[b]{2}{*}{ Solvent } & \multicolumn{2}{|c|}{ Percent of Inhibition } \\
\hline & & $\begin{array}{l}\alpha- \\
\text { Glucosidase } \\
\text { Enzyme }\end{array}$ & $\begin{array}{l}\alpha- \\
\text { amylase } \\
\text { Enzyme }\end{array}$ \\
\hline \multirow[t]{2}{*}{$\begin{array}{l}\text { Citrus } \\
\text { maxima }\end{array}$} & $\begin{array}{l}80 \% \\
\text { Acetone }\end{array}$ & $\begin{array}{ll}38.17 & \pm \\
9.71 & \end{array}$ & $\begin{array}{l}41.06 \quad \pm \\
10.94\end{array}$ \\
\hline & $\begin{array}{l}\text { Ethyl } \\
\text { Acetate }\end{array}$ & $\begin{array}{l}38.04 \\
2.01\end{array}$ & $\begin{array}{l}30.26 \quad \pm \\
11.82\end{array}$ \\
\hline \multirow[t]{2}{*}{$\begin{array}{l}\text { Citrus } \\
\text { hystrix }\end{array}$} & $\begin{array}{l}80 \% \\
\text { Acetone }\end{array}$ & $\begin{array}{l}47.16 \\
11.32\end{array}$ & $\begin{array}{l}25.47 \quad \pm \\
6.86\end{array}$ \\
\hline & $\begin{array}{l}\text { Ethyl } \\
\text { Acetate }\end{array}$ & $\begin{array}{l}43.80 \\
8.94\end{array}$ & $\begin{array}{l}26.98 \quad \pm \\
6.54\end{array}$ \\
\hline \multirow[t]{2}{*}{$\begin{array}{l}\text { Citrus } \\
\text { aurantifolia }\end{array}$} & $\begin{array}{l}80 \% \\
\text { Acetone }\end{array}$ & $\begin{array}{l}53.95 \\
14.34\end{array}$ & $\begin{array}{ll}15.63 \quad \pm \\
3.93\end{array}$ \\
\hline & $\begin{array}{l}\text { Ethyl } \\
\text { Acetate }\end{array}$ & $\begin{array}{l}41.37 \\
5.45\end{array}$ & $\begin{array}{l}39.97 \quad \pm \\
8.60\end{array}$ \\
\hline \multirow[t]{2}{*}{$\begin{array}{l}\text { Citrus } \\
\text { microcarpa }\end{array}$} & $\begin{array}{l}80 \% \\
\text { Acetone }\end{array}$ & $\begin{array}{l}61.79 \\
4.13\end{array}$ & $\begin{array}{l}32.66 \quad \pm \\
9.17\end{array}$ \\
\hline & $\begin{array}{l}\text { Ethyl } \\
\text { Acetate }\end{array}$ & $\begin{array}{l}45.30 \\
5.35\end{array}$ & $\begin{array}{l}43.99 \\
\pm 22.03\end{array}$ \\
\hline
\end{tabular}


The IC50 value of Lime peels (Citrus amblycarpa) was $125.93 \pm 9.14$ that was higher than other types of citrus peels that were shown in the table above. It means that the ability of Citrus amblycarpa as $\alpha$ Glucosidase Enzyme inhibition was not as good as the other type of Citrus.

\section{CONCLUSION}

Hence the lime peel has the potential of anti-diabetic activity that has the highest anti-diabetic activity in the $50 \mu \mathrm{g} / \mathrm{mL}$, and IC50 value ranged $125.93 \pm 9.14 \mu \mathrm{g} / \mathrm{mL}$, it is caused by the presence of some phytochemicals like flavonoid, phenol, steroid/triterpenoid, and alkaloid.

\section{REFERENCES}

American Diabetes Association (2015) Standards of Medical Care in Diabetes-2015. US: American Diabetes Association. doi: 10.2337/dc14-S014.

Apriliani, M., Ramadhan, A. M. and Rijai, L. (2017) 'Aktivitas Antibakteri Ekstrak Daun Jeruk Sambal (Citrus microcarpa) Terhadap Beberapa Bakteri Patogen', in Proceeding of Mulawarman Pharmaceuticals Conferences, pp. 157-164.

Badan Penelitian Dan Pengembangan Kesehatan Kementerian Kesehatan RI (2013) Riset Kesehatan Dasar 2013, Kementrian Kesehatan Republik Indonesia. doi: 1 Desember 2013.

Borges de Melo, E., da Silveira Gomes, A. and Carvalho, I. (2006) ' $\alpha$ - and $\beta$ Glucosidase inhibitors: chemical structure and biological activity',
Tetrahedron, 62(44), pp. 1027710302.

doi: 10.1016/j.tet.2006.08.055.

Bouabid, K. et al. (2018) 'Phytochemical screening and in vitro evaluation of alpha amylase, alpha glucosidase and beta galactosidase inhibition by aqueous and organic Atractylis gummifera L. Extracts', Plant Science Today, 5(3), pp. 103-112. doi: 10.14719/pst.2018.5.3.393.

Gondokesumo, M. E., Kusuma, H. S. W. and Widowati, W. (2017) ' $\alpha-/ \beta$ Glucosidase and $\alpha$-Amylase Inhibitory Activities of Roselle (Hibiscus sabdariffa L.) Ethanol Extract', Molecular and Cellular Biomedical Sciences, 1(1), pp. 3440. doi: $10.21705 / \mathrm{mcbs} . v 1 \mathrm{i} 1.3$.

Gordon, D. M. (2010) 'Struktur dan Fungsi Molekul Biologis Berukuran Besar', in Campbell, N. A. et al. (eds) Biologi Edisi Kedelapan Jilid 1. Jakarta: Erlangga.

Kusumaningrum, A. (2015) 'Aktivitas Minyak Atsiri Kulit Buah Jeruk Sambal (Citrus microcarpa) sebagai Repelan Terhadap Nyamuk Aedes aegypti L. dengan Metode Whopes', Jurnal Mahasiswa Farmasi Fakultas Kedokteran UNTAN, 2(1).

Lim, S. M. and Loh, S. P. (2016) 'In vitro antioxidant capacities and antidiabetic properties of phenolic extracts from selected citrus peels', International Food Research Journal.

Naquvi, K. J. et al. (2011) 'Review on Role of Natural Alpha-Glucosidase Inhibitors for Management of Diabetes Mellitus', International Journal of Biomedical Research, 2(6), pp. 374-380. doi: 10.7439/ijbr.v2i6.121.

Pujimulyani, D. et al. (2018) 'Antidiabetic and antioxidant potential of Curcuma 
mangga Val extract and fractions', Asian Journal of Agriculture and Biology.

Putra, G. M. D., Satriawati, D. A. and Astuti, N. K. W. (2018) 'Standarisasi dan skrining fitokimia ekstrak etanol $70 \%$ daun jeruk limau (Citrus amblycarpa (Hassk.) Osche)', Jurnal Kimia, 12(2), pp. 187-194.

Soegondo, S. (2017) 'Farmakoterapi pada Pengendalian Glikemia Diabetes Melitus Tipe 2', in Setiati, S. et al. (eds) Buku Ajar Ilmu Penyakit Dalam Jilid II Edisi VI. Jakarta: Interna Publishing.

Stevenie et al. (2019) 'Comparison Activities of Peel and Extract of Lime ( Citrus amblycarpa ) as Antioxidant and Antielastase', American Scientific Research Journal for Engineering, Technology, and Sciences (ASRJETS), 57(1), pp. 77-84.

Widowati, W. et al. (2011) 'Free Radical Scavenging and $\alpha$-Glucosidase Inhibitor Activity of Ethanolic Extract of Mucuna pruriens L.', JFIOnline.

Widowati, W. et al. (2014) 'Green Tea Extract Protects Endothelial Progenitor Cells from Oxidative Insult through Reduction of Intracellular Reactive Oxygen Species Activity', Iranian Journal of Basic Medical Sciences, 17(9), pp. 702-709. doi: 10.22038/ijbms.2014.3334.

Widowati, W. et al. (2016) 'Antioxidant and Anti Aging Assays of $<\mathrm{I}>$ Oryza sativa $</$ I $>$ Extracts, Vanillin and Coumaric Acid', Journal of Natural Remedies. doi: 10.18311/jnr/2016/7220.

Widowati, W. et al. (2017) 'Antioxidant and antiaging assays of Hibiscus sabdariffa extract and its compounds', Natural Product Sciences, 23(3), pp. 192-200. doi: 10.20307/nps.2017.23.3.192.

Widowati, W., Widya Janeva, B., et al. (2018) 'Antioxidant and antiaging activities of Jasminum sambac extract, and its compounds', Journal of Reports in Pharmaceutical Sciences, 7(3), pp. 270-285.

Widowati, W., Wargasetia, T. L., et al. (2018) 'Antioxidant and antidiabetic potential of Curcuma longa and its compounds', Asian Journal of Agriculture and Biology.

World Health Organization (2016) 'Global Report on Diabetes', Isbn. doi: ISBN 9789241565257. 